\title{
Do Christian and secular moralities exclude one another?
}

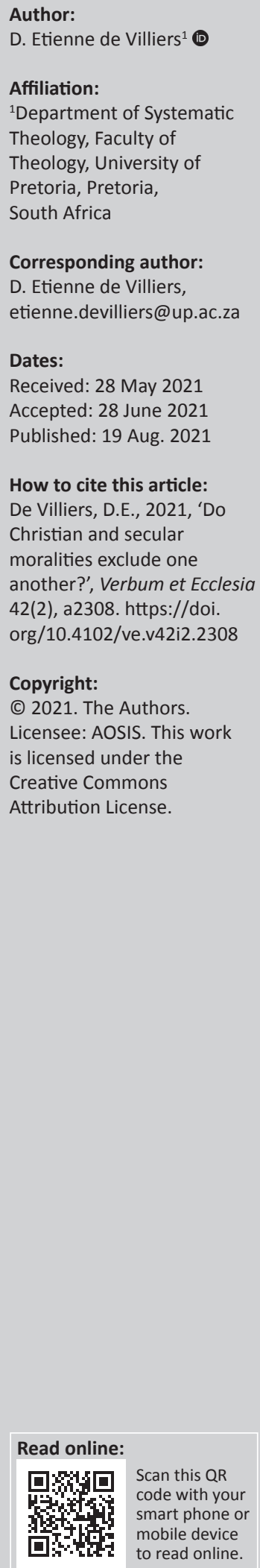

The objective of the article was to critique two cognitive strategies used by both proponents of Christian and secular moralities to justify an exclusionary relationship between them, thus contributing to the conflict between them. They are the cognitive strategies of foundationalism and incompatibilism. The objective was also to resume a critical discussion of these two strategies in Wentzel van Huyssteen's publications. The method followed was, first, to provide a historical reconstruction of the relationship between Christian faith and the secular and, second, a critical analysis of Richard Dawkins' foundationalist view of secular morality and Stanley Hauerwas' incompatibilist view of Christian morality. Findings were that influential views of a positive relationship between Christian faith and secular morality are found in history, and that the foundationalist view of Dawkins and the incompatibilist view of Hauerwas are both untenable and contextually inappropriate. This led to the conclusion that there is no justification for the view that Christian morality and secular moralities necessarily exclude one another. The remaining challenge to find an alternative approach that would allow for a more positive relationship between these two moralities and provide guidance on adaptations they need to make was also identified.

Intradisciplinary and/or interdisciplinary implications: The Christian ethical research undertaken in the article drew on research findings in the fields of Christian Ethics, Church History, philosophy, evolutionary ethics and psychology. Research results present Christian and philosophical ethics with the challenge to find an acceptable alternative for the problematic foundationalist and incompatibilist approaches.

Keywords: Christian morality; distinctiveness of Christian morality; evolutionary ethics; foundationalism; incompatibilism; origin of morality; postfoundationalism; secularisation; secular morality.

\section{Introduction}

Morality is a valuable social institution that we need to cherish. It is a social institution that still today forms an effective bulwark against the selfish pursuit of personal and group interests and provides indispensable normative orientation to our actions. However, in contemporary culture, morality is undermined in several ways. One of the undermining developments is the intensified conflict between proponents of religious and secular moralities. Proponents on both sides of the divide tend to claim sole validity for the morality they advocate and denigrate the morality advocated by their opponents. In this way, the view - a false one in my opinion - is spread that we all must choose between the two moralities. Instead of enabling transcendence of group interests, religious and secular moralities become weapons utilised in group conflict. And instead of providing meaningful normative guidance in a time when we are confronted with global problems that could only be addressed by global cooperation, the two moralities guide people to march to different tunes.

In this conflict, at least two cognitive strategies are used by proponents of both religious and secular moralities. The one is foundationalism, the cognitive strategy of claiming that the morality propagated by us is based on indubitable foundations, whilst the morality propagated by opponents is not. The other is to claim the incommensurability or incompatibility of our morality in being in all respects distinctive or unique in comparison to other moralities.

Foundationalism and incommensurability of beliefs are two themes Wentzel van Huyssteen addresses in his publications. In the introduction of his book The Shaping of Rationality: Interdisciplinarity in Theology and Science, he indicates his intention to develop an argument for

Note: Special Collection: Festschrift for Wentzel van Huyssteen. 
moving 'beyond the absolutism of foundationalism and the relativism of nonfoundationalism, to a postfoundationalist notion of rationality...' (Van Huyssteen 1999:12). His postfoundationalist approach shares much of the criticism of postmodernist philosophers and theologians against modernist assumptions about the possibility of arriving at indubitable foundations for knowledge, including moral knowledge. However, in developing this approach, he also takes a stand against postmodernist assumptions about the incommensurability of beliefs, including moral beliefs, in different communities. To quote Wentzel (1999):

[W]hile we always operate in terms of concepts and criteria that appeared in a particular culture, we are nonetheless able to transcend our specific contexts and reach out to more intersubjective levels of discussion, without necessarily falling back into any of modernity's typically totalizing metanarratives. (p. 140)

In this article, I argue in line with Wentzel's postfoundationalist approach that the view that Christian and secular moralities inevitably exclude one another is not only false but also inappropriate and irresponsible in the time in which we are living. In the first section, I point out that historically, Christian and secular moralities have for the most part been distinguished but have only in certain historical circumstances and for certain reasons been regarded as conflicting with one another. In the second section, with reference to the view of Richard Dawkins, I provide a brief sketch of the secularist argument that an adequate foundation for morality is found in biological evolution. The views of Stanley Hauerwas form the point of reference for a brief exposition of the Christian ethical argument that Christian morality is incompatible with secular morality. By critically discussing the views of these proponents of moral foundationalism and incompatibility, in the last section, I argue that such views are neither convincing nor contextually appropriate.

\section{Historical background of the exclusionary view ${ }^{1}$}

Historians mostly ascribe the origin of the distinction of the secular from the religious, the heavenly or the sacred to Augustine's City of God. Already in his earlier publications, Augustine struggled with the question whether after the Constantinian shift, the institutions and disciplines of the Roman Empire should be regarded as sinful and profane and thus be totally rejected by Christians or rather be radically Christianised and sacralised and thus be integrated into sacred history. In the City of God, he developed a view that steered between the Scylla and Charybdis of these two alternatives. He, on the one hand, took a stance against the indiscriminate demonisation of the secular institutions, disciplines and civic virtues of the earthly city. Although in his view they do not contribute to the attainment of perfect justice, they have a certain positive value in contributing to the maintenance of security, order and peace. He, on the other hand, also took a stance against the sacralisation of the earthly city. The historian Robert Markus (2020) sums up Augustine's view in this regard:

Between the Incarnation and the parousia history was, in Augustine's final view, totally 'secular', containing no signposts to sacred meaning, no landmarks in the history of salvation. In terms of their ultimate significance, in relation to salvation or damnation, history remained opaque to human scrutiny: 'In this world the two Cities are inextricably intertwined and mingled with each other, until they shall be separated in the last judgment' (Civ Dei 1.35). (p. 4)

In this way, Augustine demarcated a shared space in which pagan and Christian both have a stake, a space in which members of the two Cities (the earthly and the heavenly) make use of the same finite goods, although for different ends, with 'a different faith, a different hope, a different love' (Civ. Dei 18.45). This was the saeculum, not a third City between the earthly and the heavenly, but their mixed, 'inextricably intertwined' state in this temporal life. On the one hand, political institutions, social practices and customs are all radically relativised. At the same time, Augustine is asserting their autonomy within their restricted sphere. In a Christian perspective, they are neutral; they can be used rightly, directed to the enjoyment of eternal peace by members of the heavenly City, or wrongly, directed solely to the enjoyment of lesser goods, the earthly peace (Civ. Dei, 19.14) (Markus 2020).

What contributed to the shift from Augustine's view of the secular as a neutral space that can be recognised by both Christians and non-Christians, to the almost generally accepted view today that the secular stands in opposition to the Christian? Historically, real-life conflicts between worldly powers and the church have undeniably played an important role. More accurately, we can define these conflicts as conflicts regarding sovereignty. Already in the Middle Ages, conflicts between church and political rule flared up when one or both of them claimed to be the true executor of God's sovereignty in earthly matters. There was then the tendency to fall back on one of the alternatives of demonising or sacralising the earthly powers and to dispense with the neutral shared space of the secular demarcated by Augustine. The decisive shift only took place when faith in God's sovereignty lost its seemingly self-evident and often dominant role in public life and when sovereignty authority, power and glory - in public life increasingly belonged to earthly and human authorities and powers in a similar self-evident way.

In her book Sovereignty: God, State and Self (2008), Jean Bethke Elshtain provides an account of the historical process in which this shift in dominant views on sovereignty in public life took place. To summarise her account: during the first phase, sovereignty belongs to God; during the second phase, God's throne becomes empty and sovereignty belongs to political authorities and powers, increasingly to the sovereign 
nation state; and in the third phase, she argues, sovereignty in practice belongs to the self, the so-called autonomous and sovereign self. In her account, developments regarding sovereignty in the political sphere, more particularly the sovereignty of the nation state, stand central. Where early claims for the absolute political sovereignty of the king (e.g. by Jean Bodin for the French kings) were still legitimised by relating it to God's sovereignty, it was Jean-Jacques Rousseau in his The Social Contract (1762) who for the first time presented an influential case for the sovereignty of the nation state based on anti-Christian sentiments. In Elshtain's opinion, he sacralised political life by claiming that the general will of the people is one and cannot err. He also regarded the spirit of Christianity as incompatible with the sovereign political system favoured by him. 'One reason why Christianity is so lousy as a possible civic religion lies in the fact that its spirituality cannot rise to the occasion to defend the body politic', Elshtain explains (2008:134). No independent religious body should thus in Rousseau's opinion be allowed in the sovereign nation state. The French Revolution only took these views of Rousseau to their radical consequences.

Similar stories as this one regarding developments in the political sphere could be told about developments since the Renaissance in the spheres of science, the economy and the arts. In all of these, there were conflicts over power and influence between those who defended Christian interests and guarded against the introduction of views contravening traditional Christian beliefs and those who tried to get rid of Christian control and influence that, in their opinion, held back the advance of knowledge and progress. As a result, the secular became the domain increasingly associated by many Christians with the exclusion of Christian beliefs and even with hostility against the Christian faith. Non-Christians on their part increasingly associated the secular with the liberated earthly space purged from all influence of the church and Christian faith.

When in the 19th century, the conflict between the church and earthly powers and authorities for control over public life intensified, a new term was coined to describe the process in which the church lost control and influence in public life, namely 'secularisation'. This term (in Latin 'saecularisatio') was first used for the 'return of the religious man into the world' of Roman Catholic priests who requested to be released of their sacred vows to dedicate their lives to church ministry. 'Secularisation', however, became in 19th-century Europe the rallying cry of the conflict between the state and the church over the expropriation of ecclesiastic goods. When Max Weber formulated his famous thesis about the secularisation of Puritan asceticism in the capitalist ethics of work, the apparent neutrality of his diagnosis could not hide its function in the battle he was fighting against, amongst others, so-called Christian fanatics and false prophets. In his opinion, they disregarded the disenchantment of the world, and thus the inevitable demise of the Christian faith, as a result of irreversible modernisation processes (cf. Agamben 2011:3-4).
It cannot be denied that as a result of the role the concept of secularisation has played in the conflict between the church and earthly powers and authorities, it is historically associated with enmity. It is, however, important to recognise that this concept does not necessarily imply an adversarial or exclusionary relationship between the Christian faith and secular values. For one, 'the return of the religious man into the world' that the term 'secularisation' originally signified in many cases did not involve a rejection of the Christian faith or church, but only the return to a worldly occupation. The requirement of canon law that the secularised priest had to wear a sign of the religious order he had once belonged to does not attest to a complete severing of ties with the church. Even in the twentieth century, the concept secularisation was used by some theologians to refer to a positive relation between the Christian faith and secular values. The German theologian Friedrich Gogarten, for example, understood secularisation as a specific performance of Christian faith that, for the first time, opens the world to man in its worldliness and historicity (Gogarten 1956; cf. Agamben 2011:4).

Recently, the well-known German philosopher Jürgen Habermas, who describes himself as 'religiously unmusical', argued that there is no need for secularisation to be still a bone of contention between Christians and non-Christians. In a public discussion between him and Joseph Ratzinger, the previous pope, on the dialectics of secularisation, he proposed that cultural and social secularisation should rather be understood as a two-way learning process inviting both the traditions of the Enlightenment and Christianity to reflect on their own limits (Habermas \& Ratzinger 2005:17). The reason is that derailed modernisation does not only impact negatively on religion but also on liberal democracies. It changes beneficent and peace-loving citizens of liberal societies into selfish monades who use their subjective rights solely as weapons against one another. In the process, the solidarity with fellow citizens, including the disadvantaged, which is essential for keeping liberal societies together, is strongly undermined (Habermas \& Ratzinger 2005:26-27). Philosophers and political leaders in liberal democracies should realise that the input of religious denominations and their members is needed to strengthen societal solidarity. Not only should they show respect to religious people and refrain from denouncing religious beliefs as false, but should they also be willing to learn from them, especially about accommodating the marginalised in society in a dignified manner (Habermas \& Ratzinger 2005:30). On their part, religions should refrain from dogmatism and give up their claim to have the monopoly on interpreting reality and on prescribing how all aspects of life should be run. They should accept the secularisation of science, the neutrality of government and general freedom of religion (Habermas \& Ratzinger 2005:34).

\section{Contemporary examples of the exclusionary view}

Contemporary examples of the exclusionary view based on both the foundationalist approach and the incompatibility 
approach are found on the side of both secularist and Christian ethicists. For brevity's sake, I discuss only a secularist example of the exclusionary view based on the foundationalist approach and a Christian example based on the incompatibility approach. The view of Richard Dawkins is taken as an example of the first and the view of Stanley Hauerwas as an example of the second.

\section{Richard Dawkins}

It is conspicuous that the emphasis in secularist circles in providing a foundationalist justification for morality has during the last few decades shifted from the Enlightenment appeal to reason to an appeal to biological evolution. Richard Dawkins is counted amongst those secularists who share what Philip Kitcher calls the 'biological' hypothesis of the origin of morality (Kitcher 2011:98). ${ }^{2}$

Dawkins (2006) starts the exposition of his own version of the view that our moral sense has a Darwinian past with the remark:

On the face of it, the Darwinian idea that evolution is driven by natural selection seems ill-suited to explain such goodness as we possess or our feelings of morality, decency, empathy and pity. (p. 215)

After all, one may add, the infamous theory of 'social Darwinism' propagated in the late 19th century by Herbert Spencer concluded from Darwin's idea of the survival of the fittest that the richest nations, races and individuals are the fittest. Giving to the poor should, therefore, be discouraged as it interferes with the natural progress of evolution by allowing the poor to breed (cf. Haidt 2012:36-37, 381). Dawkins concedes that the logic of Darwinism concludes that the unit in the hierarchy of life that survives and passes through the filter of natural selection will tend to be selfish (Dawkins 2006:215). However, it is in his opinion important to realise that the unit of natural selection (i.e. the unit of selfinterest) is not the selfish organism, group, species or ecosystem, but the selfish gene. It cannot be denied that there are indeed many circumstances in which survival of the individual organism will favour the survival of the genes that ride inside it. There are nonetheless circumstances - in Dawkins' opinion not particularly rare - in which genes ensure their own selfish survival by influencing organisms to behave altruistically (Dawkins 2006:216).

According to Dawkins, those circumstances fall into two categories. A gene that programmes individual organisms to favour their genetic kin is statistically likely to benefit copies of itself. Such a gene's frequency can increase in the gene pool to the point where kin altruism becomes the norm. The other main type of altruism for which we have a well-worked out Darwinian rationale is reciprocal altruism ('You scratch my back and I scratch yours'). The living kingdom is rich in mutually beneficial relationships especially between members of different species. Birds called honeyguides, for 2011:98). example, lead honey badgers (and sometimes people) by a special enticing flight to bees' nests they cannot themselves break open in order to gain access to honey (Dawkins 2006:216-218).

Apart from kinship and reciprocation as the twin towers of altruism in a Darwinian world, there are also secondary structures that rest atop those twin pillars. Especially in human society, with language and gossip, reputation is important. One individual may have a reputation for kindness and generosity, whilst another may have a reputation for unreliability, for cheating and reneging on deals. Not only being a good reciprocator but also fostering a reputation as a good reciprocator has a definite Darwinian survival value. Altruistic giving may also be an advertisement of dominance or superiority as is the case with dominant babblers asserting their dominance by feeding subordinates. Individuals in this manner buy success, for example, in attracting mates, through costly demonstrations of superiority, including ostentatious generosity (Dawkins 2006:218-219).

Dawkins concludes that there are at least these four good Darwinian reasons for individuals to be altruistic, generous or 'moral' towards each other. He points out that for most of our prehistory, humans lived under social conditions, surrounded by kin, which would have strongly favoured the evolution of all four kinds of altruism. That raises the question: why - now that we mostly live in cities in which we are surrounded by strangers - are we still so good to each other? Dawkins answers that natural selection favours rules of thumb, which work in practice to promote the genes that built them. Rules of thumb, by their nature, sometimes misfire. Those rules of thumb promoting altruism developed in ancestral time when we had the opportunity to be altruistic only towards kin and potential reciprocators. Nowadays that restriction is no longer there, but the rules of thumb persist. We cannot help ourselves when we see a weeping unfortunate who is unrelated and unable to reciprocate (Dawkins 2006:219-221).

If, Dawkins argues, our moral sense is indeed rooted deep in our Darwinian past, predating religion, we should expect that research on the human mind would reveal some moral universals, crossing geographical and cultural barriers, and also, crucially, religious barriers. He finds such evidence in the Harvard biologist Marc Hauser's book Moral minds: How nature designed our universal sense of right and wrong (2006). Hauser asserts that our moral judgements are driven by a universal moral grammar, a faculty of the mind that evolved over millions of years to include a set of principles for building a range of possible moral systems. As with language, the principles that make up our moral grammar fly beyond the radar of our awareness. Dawkins also finds support for his own view that we do not need God, or religion, in order to be good in an empirical study conducted by Hauser with the help of the philosopher Peter Singer. The main conclusion of their study is that there is no statistically significant difference between atheists and religious people in moral 
judgements made regarding three hypothetical moral dilemmas. This provides for Dawkins evidence that religious people do not have moral intuitions different from atheists (Dawkins 2006:222-226).

Dawkins does not suffice in The God delusion with the thesis that our moral sense has its origin in biological evolution, independent from any religious influence, and is thus the same for all people. He adds to this a full-scale attack on religions, taking no heed of Habermas' admonition to show respect for religious people and to refrain from denigrating religious beliefs as false. ${ }^{3}$ In his opinion, 'religious behaviour may be a misfiring, an unfortunate by-product of an underlying psychological propensity which in other circumstances is, or once was, useful' (Dawkins 2006:174). Religious beliefs are for the most part factually false and the normative prescriptions contained in the holy books of religions, in as far as they deviate from universal moral prescriptions, often morally abhorrent (cf. Dawkins 2006:111159, 235-278). The setting of Dawkins' view on the roots of morality in biological evolution is clearly one of hostility against religions, including the Christian religion. ${ }^{4}$

\section{Stanley Hauerwas}

Seen from Stanley Hauerwas' perspective, it would be inappropriate to say that he has a view of Christian morality based on an incompatibility approach as for him 'morality' is associated too much with secular ethics and its emphasis on universal moral principles. He is of the opinion that the history of Christian ethics in the USA since Walter Rauschenbusch has shown that the use of the term 'morality' goes hand in hand with an underemphasis of Christian distinctiveness and neglect of the central role of Christian virtues (Hauerwas 1974:1-2, 2001 [1983]:71). Hauerwas, thus, prefers to stick to the term 'Christian ethics' to indicate his intention to keep theological ethics theological. In fact, a general premise of Hauerwas' Christian ethical approach is that theological assertions are intrinsically also ethical assertions because they construe reality in a specific way, and the first task of ethics is to learn to see the world rightly (Hauerwas 1981:90). More specific premises are that Christian ethics should be closely aligned with the biblical story of Jesus, that is also the story of the kingdom of God, reject the Constantinian shift and avoid being compromised by the secularist culture and universalist ethics of liberalism. ${ }^{5}$

The biblical story of Jesus reveals that the kingdom of God has already begun in the life, death and resurrection of Jesus Christ and that people find their true destiny and learn to

3.In a discussion in 2007, the 'four horsemen', Richard Dawkins, Daniel Dennett, Sam Harris and Christopher Hitchens, the four publicists who form the core of the socalled 'Neo-Atheist' movement, extensively dealt with the oft-repeated accusation that they are strident, arrogant, vitriolic or shrill (Dawkins et al. 2019:41-84).

4.An evolutionary account of the origin of morality is not necessarily adversarial towards religion. Donald Broom, for example, develops in his book, The evolution of morality and religion (2003) an account of the evolution of morality claiming that morality and religion (2003) an account of the evolution of morality claiming that

5.See for an excellent overview of Stanley Hauerwas' Christian ethics: Arne Rasmusson, The church as polis (1995), pp. 174-302. know God by following him. Salvation should be understood as primarily social in that God created a people who is bearer of the new life that Jesus Christ made possible. As Hauerwas puts it: 'The call to be part of the gospel is a joyful call to be adopted by an alien people, to join a countercultural phenomenon, a new polis called the church' (Hauerwas 1989:30). The crucial 'political' question the church as polis faces is what kind of community it should be to be faithful to the narratives central to Christian convictions.

The call to the church to be a holy people makes discipleship central in Hauerwas' account. According to him, Christian life in terms of discipleship shows that it is not something spontaneous but rather something that must be learned and therefore requires training. He compares this learning process with learning a craft through apprenticeship (Hauerwas 1991:101). This understanding of Christian discipleship requires developed ecclesial practices like discipline, forgiveness and reconciliation. By participating in these practices, typical Christian virtues such as patience and hope are formed (Hauerwas 1983:103). To be able to witness to the peaceable kingdom, Hauerwas contends, the church must be a particular kind of people formed by a particular set of virtues (Hauerwas 1985:118). On account of his characterisation of the church as an alternative community, Hauerwas asserts that the church does not have a social ethic but is a social ethic by being a paradigmatic community in the hope of providing some indication of what the world can be but is not (Hauerwas 1977:142-143).

Hauerwas is of the opinion that much of the approach to Christian ethics that characterised the early church was lost when Christianity became a state religion in the Roman empire. The Constantinian shift means that the church changes from being a minority to become the imperial religion of, with time, almost everyone. This radically changes the understanding of ethics. When the church consists of everyone, and its role is seen as civilisational religion keeping society together, Christian ethics loses its radical nature as it cannot anymore be based on resources like personal commitment and training in a discipleship lifestyle. The consequence is that a minimalistic ethics (theologically often legitimated in some form of natural law terms) is accepted, which is complemented with 'evangelical counsels' for a motivated spiritual elite. Furthermore, it is now assumed that the Christian faith should be able to give moral support and advice to the ruler, which makes the ruler the paradigm for social ethics. The crucial question becomes what the ruler and the state should do with its power. This inevitably exposes the church to the temptation of theocracy. Hauerwas (1991) says that:

$[b] y$ taking up the Roman project, Christians were attempting to further the kingdom through the power of this world, an understandable but disastrous strategy that confused the politics of salvation with the idea that in the name of God Christians must rule. (p. 39)

In contemporary society, the main enemy of radical ecclesial ethics is in Hauerwas' view Western liberal society, in which the Enlightenment project has found its main expression. 
One part of the 'liberal project' was to emancipate people from the historical particularity of their traditions and communities, which politically means that the two basic units in modern societies are the individual on the one hand and the state on the other (Hauerwas 1985:18). A consequence is the way the distinction between a private sphere (where different personal goods, which cannot be publicly argued about, can be pursued) and a public sphere (where no common good exists, but only rules for just distribution) is made. By necessity, religion as a tradition and communitybound practice is removed to the private sphere (Hauerwas 1991:69-92).

The moral languages and theories of liberal society are closely related to the basic structures of this society. One factor is the differentiation of society that tends to divide economy, politics, law, religion and morality into separate and autonomous spheres and discourses. Economy, for example, is seen as following its own laws that cannot be subordinated to morality. Another factor is the increasing pluralism that has made a common and coherent ethical discourse difficult. These factors created the distinct form of modern ethics in which the search for an objective and universal morality able to form peaceful and cooperative societies is central. It is taken for granted that moral judgements, in order to have universal validity, must abstract from specific conceptions of the good life and be based on reason as such (Hauerwas 1988:191-197). Modern ethics thus deals exclusively with the question of the right, with universally and objectively valid principles of obligation that are independent of specific preferences concerning the good life with which traditional ethics, including Christian ethics, primarily deals. This assumption, namely that there is a special sphere of morality characterised by the language of obligation, is something that Hauerwas strongly challenges (Hauerwas 1983:22).

\section{Putting the exclusionary view in place}

There are, in my opinion, two sets of reasons to reject the view that Christian and secular moralities necessarily exclude one another. The first set of reasons has to do with the untenability of this view and the second with its contextual inappropriateness in the world in which we are living.

\section{Untenability}

Richard Dawkins follows a two-pronged strategy in his attack against Christian morality. The first is to claim that morality could be completely accounted for by tracing the origin of morality to biological evolution. Through such an account, it can be shown that morality is in no respect dependent on religion. His second strategy is to provide demonstrations of the moral unacceptability of many religious beliefs and prescriptions. For our purposes, we can leave out a critical discussion of Dawkins' second strategy.

Dawkins's evolutionary account of morality consists of tracing back morality to different forms of altruism, most of them already operating in evolution before the emergence of Homo sapiens. A first critical question one can ask is: does Dawkins' evolutionary account of morality really provide a full account of morality as we understand it today? Morality, as it operates today, could hardly be explained in terms of altruism alone. In his book, The Righteous Mind (2012), social psychologist, Jonathan Haidt makes out a strong case in developing his Moral Foundations Theory that morality should not be reduced to prescriptions regarding care and the avoidance of harm and could thus not be traced back solely to the emergence of altruism in the evolutionary process. In his opinion, 'there are (at least) six psychological systems that comprise the universal foundations of the world's many moral matrices' (Haidt 2012:211). Apart from the care or harm foundation, also the liberty/oppression, the fairness / cheating, the loyalty/betrayal, the authority/subversion and the sanctity/degradation foundations constitute the field of morality (Haidt 2012:153-179, 211-214; cf. Keane 2016:72).

A more fundamental problem with Dawkins' evolutionary account of morality is that he, in tracing morality back to forms of altruism already present in certain animals, uncritically assumes that a 'moral sense' or 'moral faculty' preceded the emergence of Homo sapiens in evolution. As both Philip Kitcher and Webb Keane convincingly argue, the emergence of such behavioural features in evolution precedes the development of morality (Keane 2016; Kitcher 2011). They could at most be regarded as pre-ethical 'capacities and propensities' (Keane 2016:31, 70-71) needed for the development of morality after human beings evolved (cf. Kitcher 2011:42). ${ }^{6}$ What was crucial for the development of morality was the distinctive interaction between humans based on the use of language. This interaction enabled human beings to develop a new device to reinforce the original altruistic tendencies and to prevent the frequent faltering of cooperation found amongst primates and hominids. Kitcher (2011) is of the opinion:

The cumbersome peacemaking of our hominids is replaced by a new device, one pre-empting rupture rather than reacting to it, and in principle capable of operating in a wide variety of contexts. That device is necessary for what we think of as ethical practice. I shall call it 'capacity for normative guidance'. (p. 69)

The simplest form of normative guidance consists in the ability to transform a situation that would otherwise have been an altruism failure, using a commitment to a rule: you obey the command to give weight to the wishes of the other. Based on this ability, ethical codes developed in the course of time. According to Kitcher, such early ethical codes were multi-dimensional. Besides explicit rules, they involved categories for classifying conduct, stories that describe exemplifying actions (both commended and frowned upon), patterns of socialisation and habitual forms of behaviour (Kitcher 2011:97).

6.Commenting on the evidence that human beings have certain psychological capacities and propensities from childhood that are necessary building blocks for ethical behaviour, Keane warns: '... we should not draw from this evidence a conclusion that humans, as individual self-contained biological organisms, are genetically predisposed to ethics or morality. One plausible way to describe this genetically predisposed to ethics or morality. One plausible way to describe this
result is what has been called "starting-state nativism" (as opposed to the stronger more teleological idea of "final-state nativism")' (Keane 2016:71). 
Proponents of an evolutionary account of morality like Dawkins mostly do not deny that historically morality became entangled with religion. They, however, tend to deny any positive role for religion regarding morality. They underwrite all or some of the following theses: (1) religion is not a necessary condition for morality; (2) although in the past religions played a role in strengthening the motivation to act morally, they are in this regard not needed anymore today; (3) the content of morality developed independently, without any positive contribution from religion and (4) religions propagate beliefs and prescriptions contravening the content of morality. I would like to comment only briefly on (3). Webb Keane has, in my opinion, convincingly demonstrated that major religions played an important role in the development of influential morality systems (Keane 2016:20). They, amongst others, contributed to making moral values more explicit, thus raising the moral awareness of people, to systemising the content of morality by aspiring to overall consistency and to universalising the applicability of moral values by pushing the moral circle even wider (Keane 2016:216). In the process, they also contributed to the introduction of new moral values, and the reinterpretation of existing ones. As a result, the major religions, including the Christian religion, also developed their own distinctive moral legacies. Specifically in Western culture, secular morality incorporated many of the normative notions of the Christian ethical tradition in a secularised form, a historical fact Jürgen Habermas graciously acknowledges. ${ }^{7}$

When it comes to Stanley Hauerwas' Christian ethical view, one must, on the one hand, acknowledge that he brought about much-needed reform by reintroducing valuable aspects of Christian ethics that were to a large extent neglected in especially Protestant theology. For one, he rightly criticised the one-sided emphasis on moral norms in Christian ethics and the almost total neglect of the central role of virtues in the lives of Christians. On the other hand, he overstates his case for the centrality of distinctively Christian virtues by interpreting it in terms of the incompatibility of Christian and secular ethics. His incompatibility stance is based on two premises: (1) the crucial distinctiveness of Christian ethics lies in those elements that cannot be shared by non-Christians and (2) the prevailing life view of liberalism in the Western world, including the universal morality it propagates, is a threat to the Christian faith, and should thus be opposed by Christians.

As for Hauerwas, Christian ethics is only distinctive in so far as it cannot be shared by non-Christians. He singles out Christian virtues as they are, in his view, formed in the regular exposure to Christian narratives which are in principle distinctive. And that is why he also underplays the role of norms and principles in Christian ethics: one cannot claim that they solely derive from biblical narratives individuality and community (Habermas \& Ratzinger 2005:32). regarding God and Christ and cannot be shared by nonChristians. By doing that Hauerwas, however, does no justice to the nature of biblical ethical instruction. It can, first, not be denied that moral principles and norms form an essential part of the ethical teaching in the Bible, including the New Testament (Biggar 2011:13). Secondly, it is just not true that only the virtues found in the Bible, on account of their clear correlation with biblical narratives on God's interaction with human beings, have a distinctively Christian flavour. The biblical moral principle of justice and the command to neighbourly love, for example, also clearly correlate with God's special care for the poor and downtrodden and his indiscriminate love for all human beings. In many instances, such biblical moral principles were also at the time distinctive of Israel and the church. The fact that they, like other moral principles and norms that form part of Christian morality, can be taken over by other religious and cultural groups should not count against them. If one looks at the list of typical Christian virtues Hauerwas draws up in his book The Peaceable Kingdom: A Primer in Christian Ethics, namely service, peacemaking, humility, vulnerability, renunciation, dispossession, forgiving enemies and nonviolence (Hauerwas 1983:76-88), it would be difficult to deny that most of these virtues, taken one by one, could be taken over - and were in fact taken over - by non-Christian groups (cf. De Villiers 2012:6).

One can add that the thesis of the incommensurability of moral values (moral norms as well as moral virtues) is contradicted by the widespread adoption in history of moral values from other religions and cultures. The Old Testament authors took over moral values from Babylonian religions, the New Testament from Judaism and Hellenistic Greece, the theologians of the Middle Ages from Plato and Aristotle and the Humanists from the Christian religion. It seems quite possible to strip individual moral norms and virtues of their original distinctive connotations and incorporate them into another religious or life-view-related ethical system, whilst clothing them with new, distinctive meanings and intentions (cf. De Villiers 2018:201).

With regard to Hauerwas' assessment of liberalism as a threat to the Christian faith, I would like to make two brief remarks. First of all, he does not distinguish clearly enough between 'liberalism as a philosophy of life' and 'political liberalism'. Liberalism as a philosophy of life could justifiably be sharply criticised from a Christian perspective on account of, inter alia, its extreme individualism. When it comes to political liberalism, one has, in my opinion, to be more discriminative in one's criticism. One has to acknowledge that the doctrine of the separation of state and religion was introduced in Western history by political liberalism to counter the disastrous consequences of the religious wars in Europe on account of the close alignment of the Roman Catholic church and Protestant churches with different political powers. In a sense, the separation of state and religion that was introduced in Western democracies could be regarded as a political antidote against the Constantinian shift Hauerwas so strongly opposes. Although it is true that there are examples 
of a 'hard' separation of state and religion in certain Western democracies (e.g. in France) that entail a certain hostility against religions, there are also examples of a 'soft' separation in other Western democracies (e.g. Germany) that allow religions a certain public role by making provision for religious education in public schools and subsidising the charity work of churches.

Hauerwas is, on the one hand, right that the ethics of liberalism, in as far as it departs from the Enlightenment premise that a universal and objective morality, with a foundationalist justification, should replace particular moralities based on cultural and religious beliefs, threatens Christian ethics and should thus be rejected. On the other hand, it may be asked whether Christian ethics should associate all contemporary efforts to find shared moral values transcending the borders of particular cultures and religions with questionable foundationalism. To highlight the outcome of only one such effort: as a result of the fact that all human beings share the same physical, mental and, for the most part, social nature and needs and can suffer in a number of easily identifiable ways, there is today widespread moral consensus on the actions that can cause harm and should be avoided. There is thus also widespread consensus on the specific prohibitions the universally recognised principle of harm avoidance entails (cf. De Villiers 2014; Shapcott 2010:47, 171). The effort to strengthen the consensus on specific prohibitions concretising the principle of harm avoidance is one Christians need not reject but should rather support.

\section{Contextual inappropriateness}

The view that Christian and secular moralities necessarily exclude one another, whether based on a foundationalist or incompatibility rationale, is not only untenable but also contextually inappropriate.

The exclusionary view, first, is clearly not helpful in overcoming divisiveness in contemporary societies, increasingly characterised by cultural and religious pluralisation. It rather contributes to the increase of hostility and intolerance. When it is claimed that one set of moral values, whether secular or religious in nature, is exclusively true or valid, and other sets of moral values are denigrated as false or invalid, intolerance on the side of the group making such claims and resentment on the side of groups feeling that their moral beliefs are belittled by such claims are unavoidable. Even worse is when the impression is created that one set of moral values is benefited - by legal or other measures - at the cost of other sets of moral values.

The exclusionary view, second, maintains - in my opinion wrongly - that no cooperation based on moral grounds between adherents of Christian and secular moralities is possible, except on terms set by one of the two sides. Such an approach is highly irresponsible at a time in the history of the world when we are faced with global problems such as creeping climate change, growing economic inequality, more frequent worldwide pandemics, intensifying religious fundamentalism and spreading international terrorism. As Yuval Noah Harari rightly says: global problems need global solutions (Harari 2018:111). Global problems would only be solved by joint, coordinated and global efforts by relevant political, economic and religious role players from many countries and cultures. However, as we could already experience, it is almost impossible to successfully plan and implement such joint, global projects when there is inadequate agreement on the moral values that should guide such projects. Christian and secular moralities, underwriting an exclusionary view, clearly do not play a constructive role in building the moral consensus needed to successfully address global problems.

\section{Conclusion}

The conclusion of this article is that Christian and secular moralities do not necessarily exclude one another. Such a conclusion contravenes the exclusionary view of Christian and secular moralities based on foundationalism or incompatibilism. As ethical foundationalism and incompatibilism are both untenable and contextually inappropriate, Christian and secular moralities should, in my opinion, dispense of these approaches. This leaves us with two fundamental questions: (1) which alternative approach would be more cogent and contextually appropriate? and (2) which adaptations are needed to both Christian and secular moralities that would allow them to constructively contribute to peaceful coexistence in contemporary societies and to building the moral consensus needed for finding solutions to societal and global problems?

Without pre-empting a more thorough discussion of these questions, I would like to suggest that in the discussion of an alternative approach, Wentzel van Huyssteen's postfoundationalist approach should also be considered (cf. De Villiers 2017:251-256, 262-270). It might also be fruitful to, in the discussion of the necessary adaptations to Christian and secular morality, revisit Augustine's notion of the secular as the neutral space shared by Christians and non-Christians, consisting, amongst others, of shared moral values agreed upon by all relevant parties.

\section{Acknowledgements}

I had a fruitful exchange of ideas on the history of the concept of secular morality with Prof Dirk Smit of the Princeton Theological Seminary in New Jersey, USA.

\section{Competing interests}

The author declares that he has no financial or personal relationship that may have inappropriately influenced him in writing this article.

\section{Author's contributions}

D.E.d.V. is the sole author of this article.

\section{Ethical considerations}

This article followed all ethical standards for research without direct contact with human or animal subjects. 


\section{Funding information}

This research received no specific grant from any funding agency in the public, commercial or not-for-profit sectors.

\section{Data availability}

Data sharing is not applicable to this article as no new data were created or analysed in this study.

\section{Disclaimer}

The views and opinions expressed in this article are those of the author and do not necessarily reflect the official policy or position of any affiliated agency of the author.

\section{References}

Agamben, G., 2011, The kingdom and the glory: For a theological genealogy of economy and the government, transl. L. Chiesa with M. Manorini, Stanford University Press, Stanford, CA.

Biggar, N., 2011, Behaving in public: How to do Christian ethics, William B. Eerdmans Publishing Company, Grand Rapids, MI.

Broom, D.M., 2003, The evolution of morality and religion, Cambridge University Press, Cambridge.

Dawkins, R., 2006, The God delusion, Bantam Press, London.

Dawkins, R., Dennett, D.C., Harris, S. \& Hitchens, C., 2019, The four horsemen: The discussion that started an atheist revolution, Bantam Press, London.

De Villiers, D.E., 2012, 'The distinctiveness of Christian morality - Reflections after 30 years', Verbum et Ecclesia 33(2), Art. \#758, 1-7. http://dx.doi.org/10.4102/ve.v33i2.758

De Villiers, D.E., 2014, 'Christian and cosmopolitan ethics: Friends or foes?', in M. Rovisco \& S. Kim (eds.), Cosmopolitan, religion and the public square, pp. 161174 , Routledge, London.

De Villiers, D.E., 2017, 'Postfoundationalism and the ethic of responsibility', in C. Lilley $\&$ D.J. Pedersen (eds.), Human origins and the image of God: Essays in honor of J. Wentzel van Huyssteen, pp. 250-272, William B. Eerdmans Publishing Company, Grand Rapids, MI.

De Villiers, D.E., 2018, Revisiting Max Weber's ethic of responsibility, Mohr Siebeck, Tübingen.
Elshtain, J.B., 2008, Sovereignty: God, state, and self, The Gifford lectures, Basic Books, New York, NY

Gogarten, F., 1956, Demythologizing and history, Scribner, New York, NY.

Habermas, J. \& Ratzinger, J., 2005, Dialektik der Säkularisierung: Über Vernunft und Religion, Herder, Freiburg.

Haidt, J., 2012, The righteous mind: Why good people are divided by politics and religion, Penguin Books, London.

Harari, Y.N., 2018, 21 Lessons for the 21st century, Jonathan Cape, London.

Hauerwas, S., 1974, Vision and virtue: Essays in Christian ethical reflection, University of Notre Dame Press, Notre Dame, IN.

Hauerwas, S., 1977, Truthfulness and tragedy: Further explorations in Christian ethics, University of Notre Dame Press, Notre Dame, IN.

Hauerwas, S., 1981, A community of character: Toward a constructive Christian social ethic, University of Notre Dame Press, Notre Dame, IN.

Hauerwas, S., 1983, The peaceable kingdom: A primer in Christian ethics, University of Notre Dame Press, Notre Dame, IN.

Hauerwas, S., 1985, Against the nations: War and survival in a liberal society, Winston Press, Minneapolis, MN.

Hauerwas, S., 1988, Christian existence today: Essays on church, world, and living in between, Labyrinth Press, Durham, NC.

Hauerwas, S., 1989, Resident aliens: Life in the Christian colony (with William H. Willimon), Abingdon Press, Nashville, TN.

Hauerwas, S., 1991, After Christendom: How the church is to behave if freedom, justice, and a Christian nation are bad ideas, Abingdon Press, Nashville, TN.

Hauerwas, S., 2001 [1983], 'On keeping theological ethics theological', in J. Berkman \& M. Cartwright (eds.), The Hauerwas reader, pp. 51-74, Duke University Press, Durham, NC.

Hauser, M., 2006, Moral minds: How nature designed our universal sense of right and wrong, Harper Collins, New York, NY.

Keane, W., 2016, Ethical life: Its natural and social histories, Princeton University Press, Princeton, NJ.

Kitcher, P., 2011, The ethical project, Harvard University Press, Cambridge, MA.

Markus, R., 2020, 'Saint Augustine's secularization of Rome', Church Life Journal. A Journal of the McGrath Institute for Church Life, August 28, viewed 16 April 2021, from https://churchlifejournals.nd.edu/articles/saint-augustines-secularizationof-rome/.

Rasmusson, A., 1995, The church as polis: From political theology to theological politics as exemplified by Jürgen Moltmann and Stanley Hauerwas, University of Notre Dame Press, Notre Dame, IN.

Shapcott, R., 2010, International ethics: A critical introduction, Polity, Cambridge.

Van Huyssteen, J.W., 1999, The shaping of rationality: Toward interdisciplinarity in theology and science, William B. Eerdmans Publishing Company, Grand Rapids, MI. 